\title{
Association of body mass index and COPD exacerbation among patients with chronic bronchitis
}

\author{
Sun Hye Shin ${ }^{1 \dagger}$, Sung Ok Kwon ${ }^{2 \dagger}$, Victor Kim³${ }^{3}$, Edwin Kepner Silverman ${ }^{4}$, Tae-Hyung Kim ${ }^{5}$, Deog Kyeom Kim ${ }^{6}$,
} Yong II Hwang ${ }^{7}$, Kwang Ha Yoo ${ }^{8}$, Woo Jin Kim ${ }^{9^{*+}}$ and Hye Yun Park ${ }^{1 *+}$ (1)

\begin{abstract}
Background and objective: Chronic obstructive pulmonary disease (COPD) patients with a body mass index $(\mathrm{BMI})<25 \mathrm{~kg} / \mathrm{m}^{2}$ are prone to develop adverse event of pharmacological treatment for frequent exacerbation. As chronic bronchitis (CB) is one of the strong risk factors of exacerbation, we investigated the associations between BMI and COPD exacerbations in patients with CB.

Methods: Patients with COPD were included from the Korean COPD Subgroup Study (KOCOSS), a multicenter observational cohort study. CB was defined using the St. George's Respiratory Questionnaire and the participants were categorized according to BMl cut-off of $25 \mathrm{~kg} / \mathrm{m}^{2}$. Exacerbations during a 1-year follow-up were compared among four groups: non-CB with $B M l \geq 25 \mathrm{~kg} / \mathrm{m}^{2}$, non-CB with $B M l<25 \mathrm{~kg} / \mathrm{m}^{2}, C B$ with $B M l \geq 25 \mathrm{~kg} / \mathrm{m}^{2}$, and CB with $\mathrm{BMl}<25 \mathrm{~kg} /$ $\mathrm{m}^{2}$.

Results: Among the 1264 patients with COPD, 451 (35.7\%) had CB and 353 (27.9\%) had both CB and BMl $<25 \mathrm{~kg} / \mathrm{m}^{2}$. The COPD exacerbation risk increased across the non-CB with $B M l<25 \mathrm{~kg} / \mathrm{m}^{2}, C B$ with $B M l \geq 25 \mathrm{~kg} / \mathrm{m}^{2}$, and CB with $\mathrm{BMl}<25 \mathrm{~kg} / \mathrm{m}^{2}$ groups (adjusted incidence rate ratio [95\% confidence interval] 1.21 [0.89-1.62], 1.20 [0.77-1.88], and 1.41 [1.02-1.91], respectively, compared to the non-CB with BMI $\geq 25 \mathrm{~kg} / \mathrm{m}^{2}$ group).

Conclusions: COPD patients having both $\mathrm{CB}$ and a $\mathrm{BMl}<25 \mathrm{~kg} / \mathrm{m}^{2}$ are at higher risk of exacerbations. Considering that a $\mathrm{BMl}<25 \mathrm{~kg} / \mathrm{m}^{2}$ often limits treatment options preventing exacerbations, modified guidelines might be needed for non-obese CB patients in Asia.
\end{abstract}

Keywords: Body mass index, Chronic bronchitis, COPD, Exacerbation

*Correspondence: pulmo2@kangwon.ac.kr; hyeyunpark@skku.edu †'Sun Hye Shin and Sung Ok Kwon contributed equally to this work ${ }^{\dagger}$ Woo Jin Kim and Hye Yun Park contributed equally to this work 1 Division of Pulmonary and Critical Care Medicine, Department of Medicine, Samsung Medical Center, Sungkyunkwan University School of Medicine, 81 Irwon-ro, Gangnam-gu, Seoul 06351, Republic of Korea

${ }^{9}$ Department of Internal Medicine and Environmental Health Center, Kangwon National University Hospital, Kangwon National University School of Medicine, 156 Baengyeong-ro, Chuncheon-si, Gangwon-do 200-722, Republic of Korea

Full list of author information is available at the end of the article

\section{Background}

Acute exacerbations of chronic obstructive pulmonary disease (COPD) are associated with prolonged detrimental effects such as a decline in lung function, reduced health-related quality of life, and worse survival [1-3]. Moreover, patients with frequent or severe exacerbations are at an increased risk of further exacerbations, leading to a substantial healthcare burden associated with COPD $[4,5]$. Chronic bronchitis (CB), which is classically defined as having chronic cough and sputum for at least original author(s) and the source, provide a link to the Creative Commons licence, and indicate if changes were made. The images or other third party material in this article are included in the article's Creative Commons licence, unless indicated otherwise in a credit line to the material. If material is not included in the article's Creative Commons licence and your intended use is not permitted by statutory regulation or exceeds the permitted use, you will need to obtain permission directly from the copyright holder. To view a copy of this licence, visit http://creativecommons.org/licenses/by/4.0/. The Creative Commons Public Domain Dedication waiver (http://creativeco mmons.org/publicdomain/zero/1.0/) applies to the data made available in this article, unless otherwise stated in a credit line to the data. 
3 months for 2 consecutive years, is one of the strong risk factors of exacerbations [6-8].

For COPD patients with $\mathrm{CB}$, bronchodilators with inhaled corticosteroids (ICSs) and/or phosphodiesterase-4 (PDE-4) inhibitors are currently recommended to reduce the frequency of exacerbations. However, COPD patients with a body mass index (BMI) less than $25 \mathrm{~kg} /$ $\mathrm{m}^{2}$ are at higher risk of pneumonia with ICS use $[9,10]$, and those with a lower BMI are also prone to discontinue PDE-4 inhibitor use due to adverse events [11], making the treatment maintenances more complicated. While this $25 \mathrm{~kg} / \mathrm{m}^{2}$ BMI cut-off defines obesity in Asia-Pacific population, data from Asian countries showed that COPD patients with high BMI tend to have less symptom, better health-related quality of life and lung function, and fewer exacerbation and death, which suggests the obesity paradox [12-16].

Given that the BMI of Asian patients with COPD is consistently lower than that of Western patients [17], Asian patients with $\mathrm{CB}$ phenotype may have a different BMI distribution and a different impact of BMI on acute exacerbation compared with Western patients. We therefore conducted a multicenter cohort study to investigate the association between BMI and COPD exacerbations among Korean COPD patients with $\mathrm{CB}$, and further compared these results with data from the Genetic Epidemiology of COPD (COPDGene) study. We hypothesized that Korean patients with $\mathrm{CB}$ phenotype and $\mathrm{BMI}<25 \mathrm{~kg} / \mathrm{m}^{2}$ would have higher risk of COPD exacerbation than other patient groups.

\section{Methods}

\section{Study population and design}

The Korean COPD Subgroup Study (KOCOSS) is an ongoing, multicenter observational cohort study, which has recruited COPD patients from referral hospitals in South Korea since December 2011 [18]. Patients who were diagnosed with COPD by a pulmonologist, aged $\geq 40$ years, had a post-bronchodilator forced expiratory volume in $1 \mathrm{~s}$ /forced vital capacity $\left(\mathrm{FEV}_{1} /\right.$ $\mathrm{FVC})<0.7$, and showed respiratory symptoms were included. Detailed sociodemographic data, medical histories, questionnaires including the COPD assessment test (CAT) and the COPD-specific St. George's Respiratory Questionnaire (SGRQ-C), and results of laboratory tests, pulmonary function tests, and imaging tests were prospectively collected. This study was approved by the Institutional Review Board of each participating hospitals and written informed consent was obtained from all patients.

The COPDGene study is an observational, multicenter, longitudinal analysis of $>10,000$ subjects with at least a 10 pack-year smoking history, with and without COPD
$[19,20]$. For the comparison with the KOCOSS, we only used the data of 4479 patients with a post-bronchodilator $\mathrm{FEV}_{1} / \mathrm{FVC}<0.7$ from phase I of the COPDGene study (from January 2008 to July 2011).

\section{Chronic bronchitis and BMI}

In this study, CB was defined using the SGRQ-C, when subjects responded "almost every day" or "most days a week" to both of the questions: "Over the last 4 weeks, I have coughed" and "Over the last 4 weeks, I have brought up phlegm (sputum)". Despite the relatively short-term period assessment, this alternative definition using SGRQ has been shown to identify more subjects with $\mathrm{CB}$ phenotype, who share strikingly similar clinical and radiologic characteristics with the classically defined $\mathrm{CB}$ patients [21,22]. We used a BMI cut-off of $25 \mathrm{~kg} / \mathrm{m}^{2}$, which is known as the risk factor for pneumonia development with ICS use $[9,10]$. Study participants were categorized into four groups: non-CB with $B M I \geq 25 \mathrm{~kg} / \mathrm{m}^{2}$, non-CB with $\mathrm{BMI}<25 \mathrm{~kg} / \mathrm{m}^{2}, \mathrm{CB}$ with $\mathrm{BMI} \geq 25 \mathrm{~kg} / \mathrm{m}^{2}$, and $\mathrm{CB}$ with $\mathrm{BMI}<25 \mathrm{~kg} / \mathrm{m}^{2}$.

\section{Acute exacerbation of COPD}

The primary outcome of our analysis was the development of acute exacerbations during a 1-year follow-up. We assessed acute exacerbations based on claims data obtained from the Korean Health Insurance Review and Assessment Service (HIRA) database, by merging them with the KOCOSS data. Moderate exacerbations were defined as outpatient visits with an ICD-10 COPD code (J43.x-44.x, except J430, as the primary or within the fifth secondary diagnosis) and the prescription of systemic steroids with or without antibiotics. Severe exacerbations were defined as emergency department visits or hospitalization with an ICD-10 COPD code and the prescription of systemic steroids with or without antibiotics [23]. In the COPDGene cohort, exacerbations were selfreported using standardized questionnaires, at baseline and every 3 to 6 months during follow-up [24].

\section{Statistical analyses}

Chi-square tests or one-way analysis of variance for normally distributed data and the Kruskal-Wallis test for skewed data were used to identify differences in demographic and clinical factors among the four patient groups at baseline. To evaluate the risk of acute exacerbations of COPD during the 1-year follow-up, zero-inflated Poisson regression were applied, in which exacerbations were modeled continuously as the number of exacerbations over the 1st year after enrollment in the KOCOSS, with incidence rate ratios (IRRs) and 95\% CIs. Considering the outcome with excess zero, Poisson, zero-inflated Poisson, negative binominal, and zero-inflated negative 
binominal regressions were performed by modeling the count data of exacerbations. Based on the fit statistic of the Akaike Information Criterion (AIC) and Bayesian Information Criterion (BIC), the zero-inflated Poisson with smaller AIC and BIC values was selected. Multivariate regression analyses were also performed, using a set of different models: model 1 adjusted for age (years), sex, educational level (middle school or less vs. high school or more), smoking status (current smoker vs. ex-smoker vs. never-smoker), and post-bronchodilator $\mathrm{FEV}_{1}$ (continuous); model 2 further adjusted for use of ICS (yes vs. no), Charlson comorbidity index (continuous) and exacerbation history in the previous year (yes vs. no). For COPDGene cohort, exacerbations were dichotomized as either no exacerbation or any exacerbations over the 1st year after enrollment, and analyzed using logistic regression analysis, with odds ratios (ORs) and 95\% confidence intervals (CIs). All P values were two sided, with statistical significance defined as $\mathrm{P}<0.05$. All statistical analyses were performed using SAS 9.4 (SAS Institute, Cary, NC).

\section{Results}

\section{Study subjects}

A total of 1328 subjects with spirometry-defined COPD were enrolled in the KOCOSS from January 2012 to December 2016. Those whose records contained missing values $(n=7)$ and those who were not linked to the HIRA database $(n=57)$ were excluded. Finally, 1264 patients were included in the analysis (Fig. 1). Mean (standard deviation [SD]) age was 69.1 (7.8) years, and most participants were men $(91 \%)$. The majority of the patients were former $(64.9 \%)$ or current (26\%) smokers, while $9.1 \%$ were never smokers. Mean (SD) BMI was 22.9 (3.4) kg/ $\mathrm{m}^{2}$ (Table 1).

Participants with post-bronchodilator $\mathrm{FEV}_{1} / \mathrm{FVC}<0.7$ from KOCOSS between $2012-2016(\mathrm{~N}=1,328)$

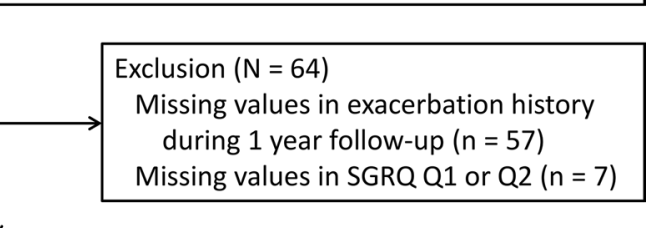

Study population for the analysis $(\mathrm{N}=1,264)$

Fig. 1 Flow diagram of the study population. *There were no missing values in BMI. BMI, body mass index; CB, chronic bronchitis; KOCOSS, Korean COPD Subgroup Study; SGRQ, St. George's Respiratory Questionnaire

\section{Distribution of $\mathrm{BMI}$ according to $\mathrm{CB}$ phenotype}

In total, 451 (35.7\%) patients had CB. Patients with CB had a significantly lower $\mathrm{BMI}$ than those without $\mathrm{CB}$ (22.5 [3.5] vs. $\left.23.1[3.3] \mathrm{kg} / \mathrm{m}^{2}, \mathrm{P}=0.003\right)$. The prevalence of underweight $\left(\mathrm{BMI}<18.5 \mathrm{~kg} / \mathrm{m}^{2}\right)$ patients were higher in $\mathrm{CB}$ group ( $13.5 \%$ vs. $8.4 \%, \mathrm{P}=0.002)$.

According to the presence of $\mathrm{CB}$ and a BMI cut-off values of $25 \mathrm{~kg} / \mathrm{m}^{2}, 230$ (18.2\%), 583 (46.1\%), 98 (7.8\%), and $353(27.9 \%)$, patients were categorized into non$\mathrm{CB}$ with $\mathrm{BMI} \geq 25 \mathrm{~kg} / \mathrm{m}^{2}$, non-CB with $\mathrm{BMI}<25 \mathrm{~kg} /$ $\mathrm{m}^{2}, \mathrm{CB}$ with $\mathrm{BMI} \geq 25 \mathrm{~kg} / \mathrm{m}^{2}$, and CB with BMI $<25 \mathrm{~kg} /$ $\mathrm{m}^{2}$ groups, respectively (Fig. 2). Patients in the $\mathrm{CB}$ with $\mathrm{BMI}<25 \mathrm{~kg} / \mathrm{m}^{2}$ group were more likely to be current smokers and have dyspnea and higher CAT and SGRQ scores than patients in the other groups. CB with $\mathrm{BMI}<25 \mathrm{~kg} / \mathrm{m}^{2}$ group also had the highest exacerbation history (31.4\%) in the previous year among four groups (Table 1).

Baseline pulmonary function test results are shown in Table 2. Compared with patients with a BMI $\geq 25 \mathrm{~kg} /$ $\mathrm{m}^{2}$, those with a $\mathrm{BMI}<25 \mathrm{~kg} / \mathrm{m}^{2}$ had significantly lower $\mathrm{FEV}_{1}$, regardless of $\mathrm{CB}$. In addition, patients in the $\mathrm{CB}$ with $\mathrm{BMI}<25 \mathrm{~kg} / \mathrm{m}^{2}$ group had a lower diffusing capacity for carbon monoxide (DLco) and more hyperinflation than those in the other groups. At baseline, about half $(51.5 \%)$ of patients in the CB with $\mathrm{BMI}<25 \mathrm{~kg} / \mathrm{m}^{2}$ group were receiving ICS-containing therapy, as triple therapy in most cases.

\section{Risk of COPD acute exacerbations during 1-year follow-up}

During the 1-year follow-up, COPD exacerbations, defined as at least one moderate or severe exacerbation, developed in 76 (33.0\%), 251 (43.1\%), 40 (40.8\%), and $184(52.1 \%)$ patients in the non-CB with $\mathrm{BMI} \geq 25 \mathrm{~kg} / \mathrm{m}^{2}$, non-CB with $\mathrm{BMI}<25 \mathrm{~kg} / \mathrm{m}^{2}$, CB with $\mathrm{BMI} \geq 25 \mathrm{~kg} / \mathrm{m}^{2}$, and $\mathrm{CB}$ with $\mathrm{BMI}<25 \mathrm{~kg} / \mathrm{m}^{2}$ groups, respectively. The unadjusted IRR for exacerbations associated with CB was 1.36 (95\% CI 1.14-1.62), while that associated with a $\mathrm{BMI}<25 \mathrm{~kg} / \mathrm{m}^{2}$ was $1.46(95 \%$ CI 1.19-1.79). Compared with that in the non-CB with $\mathrm{BMI} \geq 25 \mathrm{~kg} / \mathrm{m}^{2}$ group, the unadjusted IRR $(95 \% \mathrm{CI})$ for exacerbations was 1.43 (1.10-1.84), $1.32(0.90-1.94)$, and $1.90(1.45-2.49)$ in the non-CB with $\mathrm{BMI}<25 \mathrm{~kg} /$ $\mathrm{m}^{2}, \mathrm{CB}$ with $\mathrm{BMI} \geq 25 \mathrm{~kg} / \mathrm{m}^{2}$, and CB with $\mathrm{BMI}<25 \mathrm{~kg} /$ $\mathrm{m}^{2}$ groups, respectively. We adjusted for potential confounders including age, sex, smoking status, $\mathrm{FEV}_{1}$, ICS use, and exacerbation history in the previous year. In the fully adjusted model, the risk showed an increasing trend across the non-CB with $\mathrm{BMI}<25 \mathrm{~kg} / \mathrm{m}^{2}, \mathrm{CB}$ with $\mathrm{BMI} \geq 25 \mathrm{~kg} / \mathrm{m}^{2}$, and $\mathrm{CB}$ with $\mathrm{BMI}<25 \mathrm{~kg} / \mathrm{m}^{2}$ groups (adjusted IRR [95\% CI] 1.21 [0.89-1.62], 1.20 [0.77$1.88]$, and 1.41 [1.02-1.91], respectively, compared 
Table 1 Baseline characteristics of patients with COPD from the KOCOSS according to the presence of chronic bronchitis and BMI categories

\begin{tabular}{|c|c|c|c|c|c|c|}
\hline & \multirow[t]{2}{*}{ Total $(\mathrm{N}=1264)$} & \multicolumn{2}{|l|}{ Non-CB } & \multicolumn{2}{|l|}{ CB } & \multirow[t]{2}{*}{$P$} \\
\hline & & $\mathrm{BMI} \geq 25(\mathrm{n}=230)$ & $\mathrm{BMI}<25(\mathrm{n}=583)$ & $\mathrm{BMI} \geq 25(\mathrm{n}=98)$ & $\mathrm{BMI}<25(\mathrm{n}=353)$ & \\
\hline Age, years & $69.1 \pm 7.8$ & $68.9 \pm 7.4$ & $69.9 \pm 7.7$ & $67.5 \pm 7.9$ & $68.3 \pm 8.0$ & 0.003 \\
\hline Sex, male & $1150(91.0)$ & $200(87.0)$ & $536(91.9)$ & 89 (90.8) & $325(92.1)$ & 0.095 \\
\hline Smoking status $(N=1260)$ & & & & & & 0.002 \\
\hline Current smoker & $327(26.0)$ & $48(20.9)$ & $133(23.0)$ & $27(27.6)$ & $119(33.7)$ & \\
\hline Ex-smoker & $818(64.9)$ & $153(66.5)$ & $391(67.5)$ & $63(64.3)$ & $211(59.8)$ & \\
\hline Never smoker & $115(9.1)$ & $29(12.6)$ & $55(9.5)$ & $8(8.2)$ & $23(6.5)$ & \\
\hline Education $(N=1260)$ & & & & & & 0.118 \\
\hline Middle school or less & $727(57.7)$ & $122(53.0)$ & $327(56.4)$ & $58(59.2)$ & $220(62.5)$ & \\
\hline High school or more & $533(42.3)$ & $108(47.0)$ & $253(43.6)$ & $40(40.8)$ & $132(37.5)$ & \\
\hline Area of residence $(\mathrm{N}=1223)$ & & & & & & 0.555 \\
\hline Urban area & $481(39.3)$ & $144(63.4)$ & $338(60.4)$ & $51(54.8)$ & $209(60.9)$ & \\
\hline Rural area & $742(60.7)$ & $83(36.6)$ & $222(39.6)$ & $42(45.2)$ & $134(39.1)$ & \\
\hline CAT score $(\mathrm{N}=1253)$ & $15.2 \pm 7.8$ & $12.8 \pm 6.80$ & $13.3 \pm 7.05$ & $16.6 \pm 7.34$ & $19.4 \pm 8.07$ & $<0.0001$ \\
\hline CAT score $\geq 10$ & $931(74.3)$ & $151(65.9)$ & $387(67.2)$ & $81(83.5)$ & $312(88.9)$ & $<0.0001$ \\
\hline mMRC grade $(N=1263)$ & $1.43 \pm 0.90$ & $1.26 \pm 084$ & $1.37 \pm 0.91$ & $1.43 \pm 0.86$ & $1.65 \pm 0.90$ & $<0.0001$ \\
\hline$m M R C$ grade $\geq 2$ & $495(39.2)$ & $72(31.3)$ & $209(35.8)$ & $40(40.8)$ & $174(49.4)$ & $<0.0001$ \\
\hline \multicolumn{7}{|l|}{ SGRQ-C (N = 1259) } \\
\hline Symptom & $44.6 \pm 20.6$ & $36.2 \pm 16.0$ & $37.2 \pm 17.6$ & $55.4 \pm 19.5$ & $59.4 \pm 18.7$ & $<0.0001$ \\
\hline Activity & $46.1 \pm 23.6$ & $40.7 \pm 21.0$ & $44.0 \pm 23.3$ & $46.7 \pm 22.5$ & $53.1 \pm 24.5$ & $<0.0001$ \\
\hline Impact & $24.4 \pm 19.6$ & $18.6 \pm 16.4$ & $20.5 \pm 17.1$ & $29.3 \pm 20.2$ & $33.3 \pm 21.7$ & $<0.0001$ \\
\hline Total & $34.3 \pm 18.9$ & $28.1 \pm 15.7$ & $30.3 \pm 17.2$ & $38.8 \pm 18.6$ & $43.6 \pm 20.0$ & $<0.0001$ \\
\hline $\begin{array}{l}\text { Exacerbation in the previous } \\
\text { year }(\mathrm{N}=1253)^{\mathrm{a}}\end{array}$ & $309(24.7)$ & $41(17.9)$ & $137(23.7)$ & $21(21.6)$ & $110(31.4)$ & 0.002 \\
\hline History of asthma ( $\mathrm{N}=1253)$ & $473(37.7)$ & $86(37.4)$ & $224(39.0)$ & $32(33.0)$ & $131(37.3)$ & 0.722 \\
\hline Charlson comorbidity index (CCI) & $2.13 \pm 1.49$ & $2.35 \pm 1.42$ & $2.16 \pm 1.61$ & $2.08 \pm 1.28$ & $1.94 \pm 1.34$ & 0.010 \\
\hline $\mathrm{CCl} \geq 3$ & $363(28.7)$ & $89(38.7)$ & $162(27.8)$ & $26(26.5)$ & $86(24.4)$ & 0.002 \\
\hline
\end{tabular}

Data are presented as mean \pm standard deviation or number (\%). $P$ values $<0.05$ are presented in bold

BMI, body mass index; CAT, COPD assessment test; CB, chronic bronchitis; CCI, Charlson comorbidity index; COPD, chronic obstructive pulmonary disease; KOCOSS, Korean COPD Subgroup Study; mMRC, modified medical research council; SGRQ-C, COPD-specific St. George's Respiratory Questionnaire

${ }^{a}$ Number (\%) of the patients who experienced at least one moderate or severe acute exacerbation in the year prior to enrollment

to the non-CB with $\mathrm{BMI} \geq 25 \mathrm{~kg} / \mathrm{m}^{2}$ group) (Table 3 ). There was no interaction between the presence of $\mathrm{CB}$ and BMI categories.

\section{Comparison with COPDGene study}

Using the same inclusion and exclusion criteria for KOCOSS cohort, 3979 non-Hispanic White or African American patients with COPD were included in the analysis. Despite differences in major demographics and clinical manifestations of patients from two countries, the prevalence of $\mathrm{CB}$ was very similar between two cohorts $(35.7 \%$ in KOCOSS and $39.3 \%$ in COPDGene). However, using BMI cut-off value of $25 \mathrm{~kg} /$ $\mathrm{m}^{2}$, the proportion of $\mathrm{CB}$ with $\mathrm{BMI}<25 \mathrm{~kg} / \mathrm{m}^{2}$ group was only $13.4 \%$ in COPDGene study (Additional file 1 : Fig. S1). In COPDGene study, patients with $C B$ had a higher risk of exacerbations than those without $\mathrm{CB}$ (unadjusted OR [95\% CI] 1.85 [1.57-2.18]). However, the development of acute exacerbations did not differ according to BMI categories in COPDGene study (Additional file 2: Fig. S2).

\section{Discussion}

In the nationwide COPD cohort of South Korea, the majority of patients with $\mathrm{CB}$ had a $\mathrm{BMI}<25 \mathrm{~kg} /$ $\mathrm{m}^{2}$ and the proportion of patients with both $\mathrm{CB}$ and $\mathrm{BMI}<25 \mathrm{~kg} / \mathrm{m}^{2}$ was $28 \%$ of all COPD patients. Compared with other patient groups, those in $\mathrm{CB}$ with $\mathrm{BMI}<25 \mathrm{~kg} / \mathrm{m}^{2}$ group had more dyspnea, a poorer quality of life, and a lower lung function at baseline. During the 1-year follow-up, the risk of COPD acute exacerbations was most pronounced in patients with 


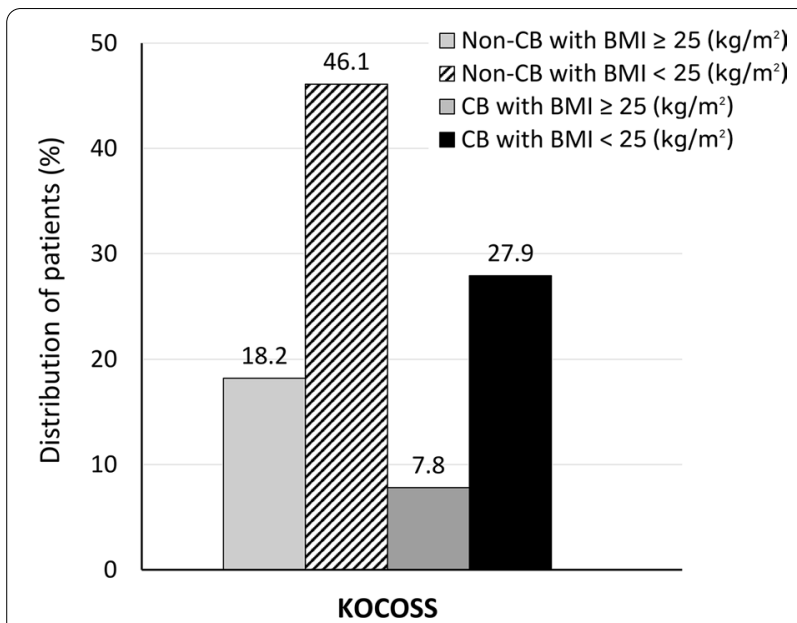

Fig. 2 Distribution of patients according to the presence of chronic bronchitis and BMI categories. BMI, body mass index; CB, chronic bronchitis; KOCOSS, Korean COPD Subgroup Study
CB with $\mathrm{BMI}<25 \mathrm{~kg} / \mathrm{m}^{2}$, even after adjustments for potential confounders. This study revealed this nonobese $\mathrm{CB}$ phenotype, who are not uncommon among Korean COPD patients, but at higher risk of COPD acute exacerbation, for whom more specific phenotypedriven approaches might be needed in clinical practice.

The prevalence of $\mathrm{CB}$ in this study was similar to that reported in the previous literature, ranging from 22 to $42 \%$ [25-27]. The presence of CB was associated with not only the previous exacerbation prior to enrollment, but also an increased risk of exacerbations during the 1-year follow-up. These findings are consistent with those of previous studies $[7,28,29]$ and emphasize the importance of identifying patients with a $\mathrm{CB}$ phenotype and managing them optimally.

The first important finding of this study is the BMI distribution according to $\mathrm{CB}$ phenotype, which showed a significantly lower $\mathrm{BMI}$ in $\mathrm{CB}$ patients compared to those without $\mathrm{CB}$. This has been previously reported in

Table 2 Baseline pulmonary function parameters and maintenance medications of patients with COPD from the KOCOSS according to the presence of chronic bronchitis and BMI categories

\begin{tabular}{|c|c|c|c|c|c|c|}
\hline & \multirow{2}{*}{ Total $(N=1264)$} & \multicolumn{2}{|l|}{ Non-CB } & \multicolumn{2}{|l|}{$\mathrm{CB}$} & \multirow[t]{2}{*}{$P$} \\
\hline & & $B M I \geq 25(n=230)$ & $\mathrm{BMI}<25(\mathrm{n}=583)$ & $B M I \geq 25(n=98)$ & $\mathrm{BMI}<25(\mathrm{n}=353)$ & \\
\hline \multicolumn{7}{|l|}{ Pulmonary function } \\
\hline Post bronchodilator FVC, L & $3.16 \pm 0.82$ & $3.14 \pm 0.84$ & $3.12 \pm 0.82$ & $3.35 \pm 0.74$ & $3.20 \pm 0.82$ & 0.046 \\
\hline $\begin{array}{l}\text { Post bronchodilator FVC, } \% \\
\text { pred }(\mathrm{N}=1262)\end{array}$ & $84.1 \pm 18.6$ & $82.4 \pm 18.9$ & $83.7 \pm 17.8$ & $84.3 \pm 15.1$ & $85.6 \pm 20.4$ & 0.203 \\
\hline Post bronchodilator $\mathrm{FEV}_{1}, \mathrm{~L}$ & $1.61 \pm 0.57$ & $1.76 \pm 0.56$ & $1.57 \pm 0.58$ & $1.82 \pm 0.52$ & $1.51 \pm 0.53$ & $<0.0001$ \\
\hline $\begin{array}{l}\text { Post bronchodilator } \mathrm{FEV}_{1}, \% \\
\text { pred }(\mathrm{N}=1262)\end{array}$ & $60.8 \pm 19.6$ & $66.2 \pm 18.8$ & $60.1 \pm 20.0$ & $65.4 \pm 15.9$ & $57.1 \pm 19.4$ & $<0.0001$ \\
\hline$\geq 80 \%$ pred & $181(14.3)$ & $46(20.0)$ & $83(14.3)$ & $16(16.5)$ & $36(10.2)$ & $<0.0001$ \\
\hline $50 \%$ pred $\leq \mathrm{FEV}_{1}<80 \%$ pred & $704(55.8)$ & $146(63.5)$ & $302(51.9)$ & $68(70.1)$ & $188(53.3)$ & \\
\hline$<50 \%$ pred & $377(29.9)$ & $38(16.5)$ & $197(33.8)$ & $13(13.4)$ & $129(36.5)$ & \\
\hline Post bronchodilator $\mathrm{FEV}_{1} / \mathrm{FVC}$ & $0.51 \pm 0.13$ & $0.56 \pm 0.11$ & $0.51 \pm 0.14$ & $0.54 \pm 0.11$ & $0.47 \pm 0.12$ & $<0.0001$ \\
\hline Bronchodilator response $\mathrm{a}^{\mathrm{a}}$ & $96(7.6)$ & $16(7.0)$ & $32(5.5)$ & $10(10.2)$ & $38(10.8)$ & 0.020 \\
\hline $\begin{array}{l}\text { Diffusing capacity, \% pred } \\
(\mathrm{N}=970)\end{array}$ & $75.3 \pm 23.8$ & $82.3 \pm 21.2$ & $76.1 \pm 25.3$ & $79.2 \pm 21.9$ & $68.4 \pm 21.7$ & $<0.0001$ \\
\hline$<60 \%$ pred & $240(24.7)$ & $20(11.3)$ & $114(26.0)$ & $14(17.3)$ & $92(33.6)$ & $<0.0001$ \\
\hline $\mathrm{RV} / \mathrm{TLC}, \%(\mathrm{~N}=754)$ & $45.0 \pm 12.8$ & $43.5 \pm 11.5$ & $46.2 \pm 13.82$ & $40.4 \pm 12.4$ & $45.4 \pm 11.8$ & 0.005 \\
\hline $6 \mathrm{MWD}, \mathrm{m}(\mathrm{N}=1003)$ & $374.8 \pm 116.5$ & $379.9 \pm 110.5$ & $379.8 \pm 118.9$ & $388.8 \pm 106.9$ & $360.0 \pm 118.0$ & 0.071 \\
\hline \multicolumn{7}{|l|}{ Baseline medication } \\
\hline No & $116(9.2)$ & $27(11.7)$ & $56(9.6)$ & $7(7.1)$ & $26(7.4)$ & 0.282 \\
\hline Yes & 1148(90.8) & 203(88.3) & $527(90.4)$ & $91(92.9)$ & $327(92.6)$ & \\
\hline $\operatorname{LAMA}(\mathrm{N}=1124)$ & $744(66.2)$ & $124(61.7)$ & $334(64.0)$ & $56(66.7)$ & $230(72.6)$ & 0.034 \\
\hline LABA $(N=1063)$ & $207(19.5)$ & $31(16.4)$ & $96(19.5)$ & $16(20.5)$ & $64(21.1)$ & 0.633 \\
\hline$I C S+L A B A(N=1082)$ & $504(46.6)$ & 77 (38.7) & $229(45.9)$ & $39(52.0)$ & $159(51.5)$ & 0.031 \\
\hline$I C S+L A B A+L A M A(N=1058)$ & $395(37.3)$ & $56(29.3)$ & $191(39.1)$ & $20(28.2)$ & $128(41.7)$ & 0.012 \\
\hline PDE-4 inhibitor $(N=1022)$ & $57(5.6)$ & $7(3.8)$ & 23(4.9) & $1(1.4)$ & $26(8.7)$ & 0.023 \\
\hline
\end{tabular}

Data are presented as mean \pm standard deviation or number (\%). $P$ values $<0.05$ are presented in bold

$\mathrm{BMI}$, body mass index; $\mathrm{CB}$, chronic bronchitis; COPD, chronic obstructive pulmonary disease; ICS, inhaled corticosteroid; FEV , forced expiratory volume in $1 \mathrm{~s}$; FVC, forced vital capacity; KOCOSS, Korean COPD Subgroup Study; LABA, long-acting beta-2 agonist; LAMA, long-acting muscarinic antagonist; PDE-4 inhibitor, phosphodiesterase-4 inhibitor; RV, residual volume; TLC, total lung capacity; 6MWD, 6-min walk distance

${ }^{a}$ Positive bronchodilator response was defined as the post-bronchodilator increase in $\mathrm{FEV}_{1}$ or FVC of at least $12 \%$ and $200 \mathrm{~mL}$ from baseline values at 15 min after inhalation of $400 \mu \mathrm{g}$ of salbutamol 
Table 3 Incidence and the risk ratios of COPD exacerbation ( $\geq 1$ moderate or $\geq 1$ severe) during 1-year follow-up according to the presence of chronic bronchitis and BMI categories in 1264 patients from the KOCOSS

\begin{tabular}{|c|c|c|c|c|c|c|}
\hline & \multirow[t]{2}{*}{ Cases/at risk } & \multirow[t]{2}{*}{ Person-years } & \multirow{2}{*}{$\begin{array}{l}\text { Incidence rate (per } \\
1000 \text { person-years) }\end{array}$} & \multirow[t]{2}{*}{ Crude IRR $(95 \% \mathrm{CI})$} & \multicolumn{2}{|c|}{ Adjusted $^{\mathrm{a}}$ IRR $(95 \% \mathrm{Cl})$} \\
\hline & & & & & Model 1 & Model 2 \\
\hline \multicolumn{7}{|l|}{ Chronic bronchitis } \\
\hline Non-CB & $327 / 813$ & 629 & 520 & Reference & Reference & Reference \\
\hline$C B$ & $224 / 451$ & 317 & 707 & $1.36(1.14-1.62)$ & $1.33(1.12-1.59)$ & $1.19(0.97-1.44)$ \\
\hline \multicolumn{7}{|l|}{ BMI $\left(\mathrm{kg} / \mathrm{m}^{2}\right)$} \\
\hline $\mathrm{BMI} \geq 25$ & $116 / 328$ & 265 & 438 & Reference & Reference & Reference \\
\hline $\mathrm{BMI}<25$ & $435 / 936$ & 681 & 639 & $1.46(1.19-1.79)$ & $1.20(0.97-1.48)$ & $1.23(0.97-1.56)$ \\
\hline \multicolumn{7}{|c|}{ Chronic bronchitis and BMI $\left(\mathrm{kg} / \mathrm{m}^{2}\right)$} \\
\hline Non- $C B$ and $B M I \geq 25$ & $76 / 230$ & 189 & 402 & Reference & Reference & Reference \\
\hline Non- $\mathrm{CB}$ and $\mathrm{BMl}<25$ & $251 / 583$ & 439 & 572 & $1.43(1.10-1.84)$ & $1.20(0.89-1.55)$ & $1.21(0.89-1.62)$ \\
\hline $\mathrm{CB}$ and $\mathrm{BMI} \geq 25$ & $40 / 98$ & 76 & 526 & $1.32(0.90-1.94)$ & $1.36(0.91-2.00)$ & $1.20(0.77-1.88)$ \\
\hline $\mathrm{CB}$ and $\mathrm{BMl}<25$ & $184 / 353$ & 241 & 763 & $1.90(1.45-2.49)$ & $1.58(1.19-2.10)$ & $1.41(1.02-1.91)$ \\
\hline
\end{tabular}

$P$ values $<0.05$ are presented in bold. BMI, body mass index; $C B$, chronic bronchitis; $C C l$, Charlson comorbidity index; $\mathrm{Cl}$, confidence interval; COPD, chronic obstructive pulmonary disease; $\mathrm{FEV}_{1}$, forced expiratory volume in $1 \mathrm{~s}$; ICS, inhaled corticosteroids; IRR, incidence rate ratios

${ }^{\text {a }}$ Model 1 was adjusted for age, sex, educational level, smoking status (current smoker vs. ex-smoker vs. never-smoker) and post bronchodilator FEV ${ }_{1}$ (continuous). Model 2 was further adjusted for ICS use (yes vs. no), CCI (continuous) and exacerbation in the previous year (yes vs. no) in addition to Model 1

the study using KOCOSS cohort, which was irrespective of CB definition (classic, SGRQ, or CAT definition) [22]. However, this is clearly different from the studies conducted in Western populations, which found that patients with $\mathrm{CB}$ had a similar or even higher BMI than those without $\mathrm{CB}[8,21,28,30,31]$, recapitulating the classic concept of "blue bloaters" [32]. Although it is a common notion that Asian patients with COPD have lower BMIs than their Western counterparts [17, 33], our study adds that Asian COPD patients with a CB phenotype have an even lower BMI than those without a $\mathrm{CB}$ phenotype.

BMI was an important risk factor for developing exacerbations in the KOCOSS cohort. In previous studies, a low BMI, weight loss, or a low fat-free mass index (FFMI) have been consistently related to increased mortality in patients with COPD [34-37]. However, the association between a low BMI and the risk of COPD exacerbations remains unclear. The Copenhagen General Population Study showed a trend of an increasing exacerbation risk in subjects with a low BMI, which, however, did not reach statistical significance [38]. In the COPDGene study, obesity $\left(B M I \geq 30 \mathrm{~kg} / \mathrm{m}^{2}\right)$ was associated with an increased risk of severe exacerbations in a dose-dependent manner [39], reflecting a U-shaped relationship, which implies that overweight patients have the lowest risk [40]. Data from Asian countries showed that obese COPD patients tend to experience fewer exacerbations [13-15]. Accordingly, our findings further document that a $\mathrm{BMI}<25 \mathrm{~kg} / \mathrm{m}^{2}$ adversely influences exacerbation risk beyond the presence of $\mathrm{CB}$ in Asian patients.
There are possible explanations for higher exacerbation risk in non-obese $\mathrm{CB}$ patients. First, compared with $\mathrm{CB}$ patients with $\mathrm{BMI} \geq 25 \mathrm{~kg} / \mathrm{m}^{2}$, those with $\mathrm{BMI}<25 \mathrm{~kg} /$ $\mathrm{m}^{2}$ had lower DLco, suggesting that this group may have higher degree of emphysema, which might have affected the increased risk of exacerbation [41, 42]. Further study including chest CT parameters such as emphysema index is needed to better define the clinical phenotypes and validate our findings. Second, a high BMI might be a marker of a greater muscle mass or better nutritional status, which are associated with better outcome in COPD $[35,43,44]$. Third, CB patient with BMI $\geq 25 \mathrm{~kg} / \mathrm{m}^{2}$ had lower residual volume/total lung capacity than those with $\mathrm{BMI}<25 \mathrm{~kg} / \mathrm{m}^{2}$, which is consistent with that higher $\mathrm{BMI}$ is associated with lesser hyperinflation (as lung volume decreases with increase in BMI) [45]. In addition to physical inactivity and deconditioning, hyperinflation has been associated with frequent exacerbation [46].

In this study, $28 \%$ of KOCOSS patients had both $\mathrm{CB}$ and a $\mathrm{BMI}<25 \mathrm{~kg} / \mathrm{m}^{2}$, and these patients were at the highest risk of exacerbations. The impact of a low BMI also extends to therapeutic choices for exacerbation prevention in Asian patients with COPD. ICS and PDE-4 inhibitors are representative medications recommended to reduce exacerbation in patients with frequent exacerbations. However, these recommendations are based on data primarily from Western populations. Indeed, prolonged use of ICS has been associated with an increased risk of pneumonia in patients with $\mathrm{BMI}<25 \mathrm{~kg} / \mathrm{m}^{2}[9$, 10]. Similarly, the reactivation of tuberculosis (TB) may complicate ICS treatment in Asian populations with a 
TB burden, as a low BMI is a notable risk factor for TB [47]. The rate of PDE-4 inhibitor discontinuation due to adverse events was also higher in Korean patients than in patients from Western countries, and this was especially observed in those with low BMI [11]. Taken together, Asian COPD patients with $\mathrm{CB}$ distinctly have a lower $\mathrm{BMI}$ than those without $\mathrm{CB}$, which increases their risk of exacerbations as well as of potential difficulties in maintaining treatment. Further studies are therefore needed to better understand this specific patient population and to set guidelines for the optimal treatment.

This study has some potential limitations. First, the KOCOSS study recruited patients with COPD from pulmonology clinics in Korea, which limits the generalizability of the findings to the entire COPD population of Asia. Second, the BMI cut-off of $25 \mathrm{~kg} / \mathrm{m}^{2}$ applied to our Korean population might be too high to define a low BMI [48]. Instead, it is more appropriate to interpret this group with $\mathrm{BMI}<25 \mathrm{~kg} / \mathrm{m}^{2}$ as "non-obese CB patients". However, when we repeated the main analysis of the KOCOSS cohort using a $23-\mathrm{kg} / \mathrm{m}^{2}$ cut-off (upper normal weight for Asian populations by the WHO [12]), we obtained similar results (Additional file 3: Table S1). We therefore decided to use a cut-off of $25 \mathrm{~kg} / \mathrm{m}^{2}$ to emphasize that while a considerable proportion of Asian patients with COPD is "non-obese CB phenotype" who are at a high risk of exacerbations and adverse event following treatment, there is a lack of treatment guidelines for this population. Third, we do not have other measures, such as FFMI using bioelectrical impedance or dual-energy X-ray absorption, or mid-thigh muscle cross-sectional area and visceral adipose tissue accumulation on $\mathrm{CT}$, which better represent body composition. Given that cachexia (based on consensus definition [37]), a low FFMI, or multi-organ loss of tissue have been shown to be more predictive of mortality in COPD [37, 42], our findings based on BMI alone need to be validated in further studies using more comprehensive measurements of anthropometry and adiposity. Finally, despite using identical definitions for $\mathrm{CB}$ and BMI cut-off values, measurements for exacerbations differed between the two cohorts. As the KOCOSS defined exacerbations using claims data, the absolute rate of exacerbations was higher than that reported in the COPDGene study, which was based on self-report questionnaires. However, we only compared the relative risks of groups within each cohort separately.

Using multicenter COPD cohorts from South Korea and the United States, we report that Korean COPD patients with a $\mathrm{CB}$ phenotype have a lower BMI than those without a $\mathrm{CB}$ phenotype, while no such difference in BMI was observed among patients in the COPDGene study. In Korean COPD patients, having both CB and a
$\mathrm{BMI}<25 \mathrm{~kg} / \mathrm{m}^{2}$ was associated with an increased risk of exacerbations even after adjustments for potential confounders, whereas exacerbation risk did not differ according to BMI in patients from the COPDGene study. Considering that a $\mathrm{BMI}<25 \mathrm{~kg} / \mathrm{m}^{2}$ often limits treatment options preventing exacerbations, more medical attention and modified guidelines are needed for non-obese CB patients in Asia.

\section{Supplementary Information}

The online version contains supplementary material available at https://doi. org/10.1186/s12931-022-01957-3.

Additional file 1: Figure S1. Distribution of patients according to the presence of chronic bronchitis and BMl categories. BMI, body mass index; CB, chronic bronchitis; COPDGene study, COPD Genetic Epidemiology study.

Additional file 2: Figure S2. The risk of COPD exacerbation* during 1-year follow-up according to the presence of chronic bronchitis and BMI categories among 3979 patients from the COPDGene study. *Exacerbation was defined as at least one mild, moderate or severe exacerbation in the COPDGene study. BMI, body mass index; CB, chronic bronchitis; COPD Genetic Epidemiology study.

Additional file 3: Table S1. Incidence and the risk ratios of COPD exacerbation ( $\geq 1$ moderate or $\geq 1$ severe) during 1-year follow-up according to the presence of chronic bronchitis and BMl categories (using cut-off $23 \mathrm{~kg} / \mathrm{m}^{2}$ ) in 1264 patients from the KOCOSS.

\section{Acknowledgements \\ None.}

\section{Authors' contributions}

Conception and design: SHS, SOK, WJK, HYP; Data collection and analysis: SHS, SOK, VK, EKS, T-HK, DKK, YIH, KHY, WJK, HYP; Data interpretation and manuscript writing: SHS, SOK, WJK, HYP; Revision of the manuscript and contribution to intellectual content: SHS, SOK, VK, EKS, T-HK, DKK, YIH, KHY, WJK, HYP. All authors contributed to critical revision of the manuscript for important intellectual content and approved of the final version. All authors read and approved the final manuscript.

\section{Funding}

This research was supported by the Research Program funded Korea National Institute of Health (2016ER670100, 2016ER670101, 2016 ER670102 and 2018ER670100, 2018ER670101, 2018ER670102, and 2021ER120500) for KOCOSS cohort and was supported by Award Number U01 HL089897 and Award Number U01 HL089856 from the National Heart, Lung, and Blood Institute. The COPDGene study (NCT00608764) is also supported by the COPD Foundation through contributions made to an Industry Advisory Committee composed of AstraZeneca, Boehringer-Ingelheim, Genentech, GlaxoSmithKline, Novartis, Pfizer, Siemens, and Sunovion.

\section{Availability of supporting data}

The KOCOSS datasets used and analyzed in this study are available from the corresponding author upon reasonable request.

\section{Declarations}

Ethical approval and consent to participate

All hospitals involved in the KOCOSS and COPDGene cohort studies obtained approval from the relevant Institutional Review Board and patients provided informed consent, including at KONKUK University Medical Center (IRB No. $\mathrm{KHH1010338).} \mathrm{The} \mathrm{patients/participants} \mathrm{provided} \mathrm{their} \mathrm{written} \mathrm{informed}$ consent to participate in this study. 


\section{Consent for publication}

Written informed consent for publication of patient clinical details was obtained from each patient.

\section{Competing interests}

None of the authors has a financial relationship with a commercial entity that has an interest in the subject of this manuscript.

\begin{abstract}
Author details
${ }^{1}$ Division of Pulmonary and Critical Care Medicine, Department of Medicine, Samsung Medical Center, Sungkyunkwan University School of Medicine, 81 Irwon-ro, Gangnam-gu, Seoul 06351, Republic of Korea. ${ }^{2}$ Biomedical Research Institute, Kangwon National University Hospital, Chuncheon, Republic of Korea. ${ }^{3}$ Lewis Katz School of Medicine at, Temple University, Philadelphia, PA, USA. ${ }^{4}$ Channing Division of Network Medicine, Division of Pulmonary and Critical Care Medicine, Department of Medicine, Brigham and Women's Hospital and Harvard Medical School, Boston, USA. ${ }^{5}$ Division of Pulmonology, Department of Internal Medicine, Hanyang University Guri Hospital, Hanyang University College of Medicine, Guri, Republic of Korea. ${ }^{6}$ Division of Pulmonary and Critical Care Medicine, Department of Internal Medicine, Seoul Metropolitan Government Seoul National University Boramae Medical Center, Seoul, Republic of Korea. ${ }^{7}$ Department of Pulmonary, Allergy and Critical Care Medicine, Hallym University Sacred Heart Hospital, Anyang, Republic of Korea. ${ }^{8}$ Department of Internal Medicine, Konkuk University School of Medicine, Seoul, Republic of Korea. ${ }^{9}$ Department of Internal Medicine and Environmental Health Center, Kangwon National University Hospital, Kangwon National University School of Medicine, 156 Baengyeong-ro, Chuncheon-si, Gangwon-do 200-722, Republic of Korea.
\end{abstract}

Received: 10 May 2021 Accepted: 11 February 2022

Published online: 07 March 2022

\section{References}

1. Donaldson GC, Seemungal TA, Bhowmik A, Wedzicha JA. Relationship between exacerbation frequency and lung function decline in chronic obstructive pulmonary disease. Thorax. 2002;57:847-52.

2. Spencer S, Calverley PM, Burge PS, Jones PW. Impact of preventing exacerbations on deterioration of health status in COPD. Eur Respir J. 2004;23:698-702.

3. Hoogendoorn M, Hoogenveen RT, Rutten-van Molken MP, Vestbo J, Feenstra TL. Case fatality of COPD exacerbations: a meta-analysis and statistical modelling approach. Eur Respir J. 2011;37:508-15.

4. Hurst JR, Vestbo J, Anzueto A, Locantore N, Mullerova H, Tal-Singer R, et al. Susceptibility to exacerbation in chronic obstructive pulmonary disease. N Engl J Med. 2010;363:1128-38.

5. Mullerova H, Maselli DJ, Locantore N, Vestbo J, Hurst JR, Wedzicha JA, et al. Hospitalized exacerbations of COPD: risk factors and outcomes in the ECLIPSE cohort. Chest. 2015;147:999-1007.

6. Burgel PR, Nesme-Meyer P, Chanez P, Caillaud D, Carre P, Perez T, et al. Cough and sputum production are associated with frequent exacerbations and hospitalizations in COPD subjects. Chest. 2009;135:975-82.

7. Kim V, Han MK, Vance GB, Make BJ, Newell JD, Hokanson JE, et al. The chronic bronchitic phenotype of COPD: an analysis of the COPDGene Study. Chest. 2011;140:626-33.

8. de Oca MM, Halbert RJ, Lopez MV, Perez-Padilla R, Talamo C, Moreno D, et al. The chronic bronchitis phenotype in subjects with and without COPD: the PLATINO study. Eur Respir J. 2012;40:28-36.

9. Crim C, Calverley PM, Anderson JA, Celli B, Ferguson GT, Jenkins C, et al. Pneumonia risk in $\mathrm{COPD}$ patients receiving inhaled corticosteroids alone or in combination: TORCH study results. Eur Respir J. 2009;34:641-7.

10. Crim C, Dransfield MT, Bourbeau J, Jones PW, Hanania NA, Mahler DA, et al. Pneumonia risk with inhaled fluticasone furoate and vilanterol compared with vilanterol alone in patients with COPD. Ann Am Thorac Soc. 2015;12:27-34.

11. Kim KH, Kang HS, Kim JS, Yoon HK, Kim SK, Rhee CK. Risk factors for the discontinuation of roflumilast in patients with chronic obstructive pulmonary disease. Int J Chron Obstruct Pulmon Dis. 2017;12:3449-56.

12. Lim JU, Lee JH, Kim JS, Hwang Yl, Kim TH, Lim SY, et al. Comparison of World Health Organization and Asia-Pacific body mass index classifications in COPD patients. Int J Chron Obstruct Pulmon Dis. 2017;12:2465-75

13. Suzuki M, Makita H, Ito YM, Nagai K, Konno S, Nishimura M. Clinical features and determinants of COPD exacerbation in the Hokkaido COPD cohort study. Eur Respir J. 2014;43:1289-97.

14. Wei YF, Tsai YH, Wang CC, Kuo PH. Impact of overweight and obesity on acute exacerbations of COPD—subgroup analysis of the Taiwan Obstructive Lung Disease cohort. Int J Chron Obstruct Pulmon Dis. 2017:12:2723-9.

15. Jo YS, Kim YH, Lee JY, Kim K, Jung KS, Yoo KH, et al. Impact of BMI on exacerbation and medical care expenses in subjects with mild to moderate airflow obstruction. Int J Chron Obstruct Pulmon Dis. 2018;13:2261-9.

16. Yamauchi Y, Hasegawa W, Yasunaga H, Sunohara M, Jo T, Takami K, et al. Paradoxical association between body mass index and in-hospital mortality in elderly patients with chronic obstructive pulmonary disease in Japan. Int J Chron Obstruct Pulmon Dis. 2014;9:1337-46.

17. Rhee CK, Chau NQ, Yunus F, Matsunaga K, Perng DW. Management of COPD in Asia: a position statement of the Asian Pacific Society of Respirology. Respirology. 2019;24:1018-25.

18. Lee JY, Chon GR, Rhee CK, Kim DK, Yoon HK, Lee JH, et al. Characteristics of patients with chronic obstructive pulmonary disease at the first visit to a Pulmonary Medical Center in Korea: The KOrea COpd Subgroup Study Team Cohort. J Korean Med Sci. 2016;31:553-60.

19. Regan EA, Hokanson JE, Murphy JR, Make B, Lynch DA, Beaty TH, et al. Genetic epidemiology of COPD (COPDGene) study design. COPD. 2010;7:32-43.

20. Maselli DJ, Bhatt SP, Anzueto A, Bowler RP, DeMeo DL, Diaz AA, et al. Clinical epidemiology of COPD: insights from 10 years of the COPDGene Study. Chest. 2019;156:228-38.

21. Kim V, Crapo J, Zhao H, Jones PW, Silverman EK, Comellas A, et al. Comparison between an alternative and the classic definition of chronic bronchitis in COPDGene. Ann Am Thorac Soc. 2015;12:332-9.

22. Choi JY, Yoon HK, Shin KC, Park SY, Lee CY, Ra SW, et al. CAT Score and SGRQ definitions of chronic bronchitis as an alternative to the classical definition. Int J Chron Obstruct Pulmon Dis. 2019;14:3043-52.

23. Lee J, Jung HM, Kim SK, Yoo KH, Jung KS, Lee SH, et al. Factors associated with chronic obstructive pulmonary disease exacerbation, based on big data analysis. Sci Rep. 2019;9:6679.

24. Wells JM, Washko GR, Han MK, Abbas N, Nath H, Mamary AJ, et al. Pulmonary arterial enlargement and acute exacerbations of COPD. N Engl J Med. 2012;367:913-21.

25. Pelkonen M, Notkola IL, Nissinen A, Tukiainen H, Koskela H. Thirty-year cumulative incidence of chronic bronchitis and COPD in relation to 30-year pulmonary function and 40-year mortality: a follow-up in middleaged rural men. Chest. 2006;130:1129-37.

26. Oh YM, Bhome AB, Boonsawat W, Gunasekera KD, Madegedara D, Idolor $L$, et al. Characteristics of stable chronic obstructive pulmonary disease patients in the pulmonology clinics of seven Asian cities. Int J Chron Obstruct Pulmon Dis. 2013;8:31-9.

27. Kim WJ, Yim JJ, Kim DK, Lee MG, Fuhlbrigge AL, Sliwinski P, et al. Severe COPD cases from Korea, Poland, and USA have substantial differences in respiratory symptoms and other respiratory illnesses. Int J Chron Obstruct Pulmon Dis. 2017:12:3415-23.

28. Corhay JL, Vincken W, Schlesser M, Bossuyt P, Imschoot J. Chronic bronchitis in COPD patients is associated with increased risk of exacerbations: a cross-sectional multicentre study. Int J Clin Pract. 2013;67:1294-301.

29. Mejza F, Gnatiuc L, Buist AS, Vollmer WM, Lamprecht B, Obaseki DO, et al. Prevalence and burden of chronic bronchitis symptoms: results from the BOLD study. Eur Respir J. 2017;50:1700621.

30. Guerra S, Sherrill DL, Bobadilla A, Martinez FD, Barbee RA. The relation of body mass index to asthma, chronic bronchitis, and emphysema. Chest. 2002;122:1256-63.

31. Sundh J, Johansson G, Larsson K, Linden A, Lofdahl CG, Sandstrom T, et al. The phenotype of concurrent chronic bronchitis and frequent exacerbations in patients with severe COPD attending Swedish secondary care units. Int J Chron Obstruct Pulmon Dis. 2015;10:2327-34.

32. Dornhorst AC. Respiratory insufficiency. Lancet. 1955;268:1185-7.

33. Lee H, Shin SH, Gu S, Zhao D, Kang D, Joi YR, et al. Racial differences in comorbidity profile among patients with chronic obstructive pulmonary disease. BMC Med. 2018;16:178. 
34. Prescott E, Almdal T, Mikkelsen $\mathrm{KL}$, Tofteng $\mathrm{CL}$, Vestbo J, Lange P. Prognostic value of weight change in chronic obstructive pulmonary disease: results from the Copenhagen City Heart Study. Eur Respir J. 2002;20:539-44.

35. Vestbo J, Prescott E, Almdal T, Dahl M, Nordestgaard BG, Andersen T, et al. Body mass, fat-free body mass, and prognosis in patients with chronic obstructive pulmonary disease from a random population sample: findings from the Copenhagen City Heart Study. Am J Respir Crit Care Med. 2006;173:79-83

36. Guo Y, Zhang T, Wang Z, Yu F, Xu Q, Guo W, et al. Body mass index and mortality in chronic obstructive pulmonary disease: a dose-response meta-analysis. Medicine (Baltimore). 2016;95:e4225.

37. McDonald MN, Wouters EFM, Rutten E, Casaburi R, Rennard SI, Lomas DA, et al. It's more than low BMl: prevalence of cachexia and associated mortality in COPD. Respir Res. 2019;20:100.

38. Colak Y, Afzal S, Lange P, Nordestgaard BG. High body mass index and risk of exacerbations and pneumonias in individuals with chronic obstructive pulmonary disease: observational and genetic risk estimates from the Copenhagen General Population Study. Int J Epidemiol. 2016;45:1551-9.

39. Lambert AA, Putcha N, Drummond MB, Boriek AM, Hanania NA, Kim $V$, et al. Obesity is associated with increased morbidity in moderate to severe COPD. Chest. 2017;151:68-77.

40. Landbo C, Prescott E, Lange P, Vestbo J, Almdal TP. Prognostic value of nutritional status in chronic obstructive pulmonary disease. Am J Respir Crit Care Med. 1999;160:1856-61.

41. Kim V, Sternberg AL, Washko G, Make BJ, Han MK, Martinez F, et al. Severe chronic bronchitis in advanced emphysema increases mortality and hospitalizations. COPD. 2013;10:667-78.

42. Celli BR, Locantore N, Tal-Singer R, Riley J, Miller B, Vestbo J, et al. Emphysema and extrapulmonary tissue loss in COPD: a multi-organ loss of tissue phenotype. Eur Respir J. 2018;51:1702146.

43. Marquis K, Debigaré R, Lacasse Y, LeBlanc P, Jobin J, Carrier G, et al. Midthigh muscle cross-sectional area is a better predictor of mortality than body mass index in patients with chronic obstructive pulmonary disease. Am J Respir Crit Care Med. 2002;166:809-13.

44. Schols AM, Broekhuizen R, Weling-Scheepers CA, Wouters EF. Body composition and mortality in chronic obstructive pulmonary disease. Am J Clin Nutr. 2005;82:53-9.

45. Guenette $J A$, Jensen $D, O^{\prime}$ Donnell $D E$. Respiratory function and the obesity paradox. Curr Opin Clin Nutr Metab Care. 2010;13:618-24.

46. Zaman M, Mahmood S, Altayeh A. Low inspiratory capacity to total lung capacity ratio is a risk factor for chronic obstructive pulmonary disease exacerbation. Am J Med Sci. 2010;339:411-4.

47. Leung CC, Lam TH, Chan WM, Yew WW, Ho KS, Leung G, et al. Lower risk of tuberculosis in obesity. Arch Intern Med. 2007;167:1297-304.

48. Jee SH, Sull JW, Park J, Lee SY, Ohrr H, Guallar E, et al. Body-mass index and mortality in Korean men and women. N Engl J Med. 2006;355:779-87.

\section{Publisher's Note}

Springer Nature remains neutral with regard to jurisdictional claims in published maps and institutional affiliations.

Ready to submit your research? Choose BMC and benefit from:

- fast, convenient online submission

- thorough peer review by experienced researchers in your field

- rapid publication on acceptance

- support for research data, including large and complex data types

- gold Open Access which fosters wider collaboration and increased citations

- maximum visibility for your research: over $100 \mathrm{M}$ website views per year

At BMC, research is always in progress.

Learn more biomedcentral.com/submissions 